\title{
Die kritiek op die fundamentalisme: 'n vorm van teologiese liberalisme?*
}

\author{
A G van Aarde
}

Sedert Karl Barth het die Skrifleer binne die raamwerk van "Fundamentalisme" versus "Liberalisme" gewentel. Hoewel hierdie diskussie internasionaal verskeie brandpunte gehad het en steeds het, word dit op hierdie moment in die Suid-Afrikaanse konteks sonder enige sodanige fokuspunte gevoer. "Fundamentalisme" versus " $\mathrm{Li}$ beralisme" is breedweg die raamwerk van die polemiek. "Liberalisme" word egter altyd op die ou end in een punt verenig, naamlik die aanslag op die Skrifgesag.

Die name van Suid-Afrikaanse teoloë word om geen ander rede in die onderhawige stuk bygehaal as omrede die feit dat dit alleen hulle is wat swart op wit ter sake is. Dit is dus nie my motief om vir enigiemand pa te staan nie - andersgesind sou ek my kritiese fakulteit moes prysgee. Ek is alleen in die vraag geinteresseerd of professore W S Vorster en J A Loader se kritiek op die fundamentalisme (eersgenoemde baie indirek van aard) ' $n$ vorm van teologiese liberalisme is, soos wel beweer word - teologiese liberalisme dan in die sin van die aanslag op die Skrifgesag.

Die mees resente dokument (waarop ek my hand kon lê) waarin beweer word dat Vorster en Loader "ontspoor" het, is dié van L F Schulze (1980: 27-39). Hierin word gesê: "Gedurende die laaste paar jaar is ons in Suid-Afrika hardhandig uit ons isolement geruk en skielik lewensgroot gekonfronteer met die probleem van die Skrifgesag. Ek verwys hier na W S Vorster ... Vervolgens na J A Loader " ... (bl 27). Hierdie "paar jaar" het in 1977 'n aanvang geneem. In dié jaar, met verwysing na Vorster, beweer J C Coetzee (1977 a: 1): “Die groot aanslag teen die Skrifgesag soos bely in ons Gereformeerde Belydenisskrifte, het nou tot op ons drumpel gekom!" Sedertdien het hierdie besorgdheid deurlopend vorendag gekom; soms direk, soms by wyse van insinuasie; meesal sonder voorbeelde.

Waarin, volgens die beswaardes, bestaan Vorster en Loader se beweerde aanslag teen die Skrifgesag? Schulze (1980: 37) insinueer dat hulle 'n Skrifbeskouing huldig wat 'n stuk "liberale rasionalis$m e$ " is. So 'n Skrifbeskouing het nie soos die Reformatore "eerbied vir die Skrif" nie deurdat dit die "werk van God in die openbaring en teboekstelling van die Skrif" (a) relativeer, (b) verpsigologiseer en (c) verkontekstualiseer. Wat met hierdie kategorieë presies bedoel

*Voordrag gelewer voor die Hervormde Teologiese Vereniging op 27 Februarie 1981. 
word, is nie sonder meer duidelik nie. Ek kan wel raai. Ter wille van teologiese refleksie noem ons vyf punte wat, meen ek, verteenwoordigend van die breë spektrum van besorgdheid is:

(a) Die werk van die Heilige Gees word geïgnoreer.

(b) Die Bybel is "tekste oor God."

(c) Die perspicuitas van die Bybel word nie erken nie.

(d) Die "ou" Bybel moet met 'n "nuwe" Bybel vervang word.

(e) Die Bybel word nie as "ons hele wysheid" aanvaar nie.

\section{Die werk van die Heilige Gees word geïgnoreer}

Ons bespreek hierdie punt eerste, maar baie kortliks. Al die ander punte van kritiek het direk of indirek te doen met die bewering (wat aaneen soos 'n refrein gehoor word) dat die werk van die Heilige Gees by sowel (a) die teboekstelling van die Bybel as (b) by die eksegese van die Bybel geïgnoreer word.

Enersyds word gesê dat Loader 'n "ten diepste skeiding" tussen die werk van die Heilige Gees en die werk van die Bybelouteurs maak (Lion-Cachet 1980: 1) en andersyds dat Vorster, behalwe vir'n sydelingse opmerking, geen aandag gee aan die feit dat die Heilige Gees die "eintlike Outeur" èn die "eintlike Eksegeet" is nie (Coetzee 1979: 11).

Hierdie verwyt is onnodig. Wanneer ' $n$ mens na die standaardverwysing van die sogenoemde "tradisionele Gereformeerde" hermeneutiek (Coetzee 1979: 12 se terminologie) kyk, naamlik die werke van Greijdanus (1946) en Grosheide (1935), kan dieselfde beskuldiging ten opsigte van hulle gemaak word. Want: "By albei word nie veel aandag aan die Heilige Gees as eksegeet gegee nie" (De Klerk 1978: 43 nota 22). Die rede waarom daar in die besinning oor die ontstaan en verstaan van die Bybel met 'n "sydelingse opmerking" volstaan word, hou klaarblyklik verband met die feit dat die werk van die Heilige Gees in dié verband in die teologie binne die raamwerk van die inspirasieleer val. ' $n$ Bewering dat Vorster en Loader nie aan die inspirasie van die Gees sou vashou nie, sou gewoonweg onbillik wees. Die verskil in opinie bestaan oor die aard (meganiesorganies- aktualisties- ensovoorts) en die plek van die inspirasieleer in die eksegeties-hermeneutiese proses. Die aard van die inspirasie is vir Gereformeerdes/Hervormers ' $n$ kwessie van interpretasie van NGB Artikel III. Omdat sommige reken dat die belydenisskrifte, as konsensus van die Gereformeerde eksegese van die eeue, die "vertrekpunt" van die eksegese moet wees (Coetzee, De Klerk, Floor 1980: $22 \mathrm{v}$ ) en ander nie, maak laasgenoemde nie minder reformatories nie. Gerugsteun deur die reformatoriese spreuk sola scriptura kan daar eerder 'n saak uitgemaak word dat die Skrif sonder "belydenisdwang" aan die woord moet kom (Pelser s.j. :65v; Roberts 1977: 
22v). Die belydenisskrifte het sy onvervreembare reg binne die Gereformeerde teologie, maar nooit ten koste van die Skrif self nie.

Agter die ontstaan van die Bybel, is ' $n$ daad van die verlossende God. Dit kan "inspirasie" genoem word. Die gelowige hoor, verkondig en gehoorsaamwees van die mens op grond van dié daad van God, kan ook "inspirasie" genoem word. Ons theologumena oor die verband tussen dié twee aspekte is suiwer geloofs-apriories van aard. Tekste in die Nuwe Testament (veral by Paulus) oor die Heilige Gees moet nie buite hulle kontekstuele funksionaliteit gebruik word om vanuit die gesigspunt van ' $n$ bepaalde inspirasiesisteem 'n ongeregverdigde verband tussen die werk van die Gees en dié van 'n mens te reguleer nie (soos De Klerk 1978). Sommige Nuwe-Testamentskrywers het inderdaad die oortuiging gehad dat die Skrif (Ou Testament) ' $n$ mega mustērion (kyk Ef 5:32) is waarvan die interpretasie alleen bekombaar is deur die geloof in Jesus Christus en daarom deur die insig in dit wat die Heilige Gees deur die Skrif sê (kyk 2 Kor 3:17a). "This view of their task does not preclude the New Testament writers from using logic or hermeneutical rules and methods. However, it does disclose where the ultimate appeal and authority of their interpretation lie. Correspondingly, an acceptance of their interpretation of Scripture in preference to some other, ancient or modern, also will rest ultimately not on the proved superiority of their logical procedure or exegetical method but rather on the conviction of their prophetic character and role" (Ellis 1978: 172. My kursivering).

Verder is dit ook disputeerbaar of daar vandag in alle opsigte (of in enige opsig) by Calvyn ten opsigte van die inspirasieleer stilgestaan moet word. Die probleem is dat Calvyn op een plek niks anders as 'n meganiese inspirasie huldig nie en op 'n ander plek die presiese teendeel. As Calvyn dan blykbaar onwillig is om op dié vraag te antwoord, lyk dit of ons maar moet ophou om sonder inagneming van die sestiende eeuse konteks dié tipe vrae aan hom (of Luther) te stel. Wanneer daar onder die vaandel van die term "inspirasie" allerlei ouderwetse eksegeties-hermeneutiese dwangreëls vir vandag afgelei word, kan die vraag tereg afgevra word of dié term nog vandag in die teologie bruikbaar is (Barr 1958: 90).

\section{Die Bybel is "tekste oor God"}

Met hierdie opskrif vat ek onder twee punte verskeie aspekte van Vorster en Loader se Skrifbeskouing saam (sonder om te sê dat dit by beide in alles simfonieer) wat na bewering om bekering (Coetzee 1977 a: 1) roep:

(a) Verkeerde verband tussen Woord van God en Bybel.

(b) Openbaringsgeskiedenis in die Bybel word ontken. 


\subsection{Verkeerde verband tussen Woord van God en Bybel}

Dit was Karl Barth wat in sy poging om die eenheid tussen wetenskap en teologie, ' $n$ reformatoriese erfenis (Stuhlmacher 1971: 124; 1979: 162), te herstel, die dialektiese vraag tussen Openbaringswoord en mensewoord aan die orde gestel het. Sedertdien het die hermeneutiek as 'n besinning oor die "reëls vir die eksegese" verander na die "teorie oor die verstaan." (Coetzee, De Klerk, Floor 1980: 12 kies doelbewus om by eersgenoemde te bly staan.) Hiermee saam het daar ook ' $n$ ander verskuiwing in die hermeneutiek ingetree: die beslissende vraag is nie meer dié na die verhouding "goddelik/menslik" nie, maar wel die vraag na die verhouding "antiek/modern" (Barr 1973: 20).

Vorster en Loader neem daarom in hierdie verband nie 'n geïsoleerde posisie in nie. Hulle staan kniediep binne die huidige teologiese worsteling om insig hoe die Bybel as antieke dokument in ' $n$ moderne wêreld kan kommunikeer. Vir 'n "kommer" en "ywer" hiervoor kan 'n Protestant nie anders as om waardering te hê nie (soos Coetzee 1974: 4 vir Vorster), al stem ons nie met die detail van die probeerslae saam nie (anders as die gesindheid van onder andere Floor 1980: 1,3). Die beswaar gaan dus nie wesenlik oor die vraag na die aktualisering van die Bybelboodskap vir vandag nie, maar oor Vorster (en Loader) se siening van die aard van die Bybel. Is die Bybel woord van God of die religieuse antwoord van die mens?

Die onderhawige polemiek word vanuit ' $n$ totaal verskil van twee teologiese kontekste gevoer: voor-Barthiaans (Reformasie $\rightarrow$ Aufklärung) en na-Barthiaans (Dialektiek $\rightarrow$ James Barr). Soos laasgenoemde nie sonder sy geskiedenis is nie, só ook eersgenoemde. Calvyn en Luther het in hulle Skrifbeskouing ' $n$ brug tussen die Middeleeuse Fransiskaanse (sensus allegoricus) en Aquiniaanse (sensus historicus) opvattinge geslaan (Frör 1967: 23 v; Stuhlmacher 1979: 94). Dit kan onder andere gesien word in hulle uitruilbare theologumena oor die werk van God en dié van die menslike outeur by die ontstaan van die Bybel. Daarom dat die Bybel volgens Calvyn 'n skriftelike samevatting van ' $n$ omvattender mondelinge spreke van God is. Die konsekwensies van hierdie sintese van goddelike en menslike arbeidsaamheid is eers in die daaropvolgende tye raakgesien en verder gevoer. Die soektog na "die pêrel in die oester" het begin, soos Deist (1979: 41) die teologiese vraag na die verband "goddelik/menslik" in die Bybel treffend beskryf. Na vele bevindinge (Luther met sy Sachmitte: "Christum-treiben"; Semler met sy "ewige Vernunftwahrheit"; Barth: "Jesus Christus als Offenbarungszeugnis"; Bultmann: "Christus-Kerygma"; Fuchs se "new quest nach dem historischen Jesus als Sprachereignis") het onder andere James Barr, en Vorster en Loader in navolging van Barr, 
gekom en gesê dat die verband "goddelik/menslik" nie 'n saak van rasionele bewysvoeringe is nie, maar 'n geloofsbelydenis. Die saligheid hang daarom nie daarvan af of die wyse waarop God met elke Bybelpassasie (en met die mens se gelowige antwoord daarop) in verband staan, raakgesien is nie. Dit is überhaupt dan ook nie nodig om dié verband te soek nie (Barr 1966: $101 \mathrm{v}$ ).

Is die siening van Barr nie 'n legitieme konsekwensie van die reformatore se bovermelde onuitgewerkte sintese nie? Is Vorster van die Reformatore ver verwyderd wanneer hy die uitdrukking "tekste oor God" uitruilbaar gebruik met "tekste wat God deur mense laat skryf het" ..., of tekste wat "deur die toedoen van God daargestel is" (HTS 35/1 \& 2, 128)? Het Loader van sy reformatoriese verlede "ontspoor" wanneer hy sê: ... (ek) "glo ook dat die Ou Testament (= Bybel; my invoeging) die woord van God is ... Dit kan ons nie wetenskaplik bewys nie. Dit is 'n saak van die geloof" (HTS 34/1 \& 2, 12)? Die crux van die probleem is myns insiens geleë in die feit dat sekere mense nie ontdaan kan raak nie van ' $n$ agterdog in dié verband wat eerder binne die eeu van die Verligting tuishoort.

Die argument word derhalwe gebruik dat 'n uitspraak dat die Bybel "menslike foute" kan bevat, 'n aanslag teen die Skrifgesag is. Barr (1977: 40) se waarneming is dus reg: "The point of conflict between fundamentalists and others is not over literality but over inerrancy ... What fundamentalists insist is not that the Bible must be taken literally but that it must be so interpreted as to avoid any admission that it contains any kind of error."

In die onderhawige polemiek word twee redes aangevoer waarom die Bybel nie foute kan bevat nie:

Eerstens, die Bybel self getuig byvoorbeeld dat Moses die eerste vyf boeke daarvan geskryf het, dat die ses dae van die skeppingsberig letterlik opgeneem moet word en dat die boeke Daniël en Ester ' $n$ "openbaringsgeskiedenis" weergee (Lion-Cachet 1980: 1 teenoor Loader). Op dieselfde trant word Vorster skerp gekritiseer oor sy mening dat die evangelies "vertelmateriaal" is met 'n binnetekstuele "vertelde wêreld" waarvan die besonderhede nie noodwendig na die "werklike wêreld" hoef te verwys nie (1977: 18v; 1980: 27-48): "mense in húlle propaganda suig dinge uit die duim ... Maar moet die Gees juis van 'stories' gebruik maak? Nee ... omdat die feite van Jesus ... magtige dade van God se heil in die geskiedenis is!" (Coetzee 1977 c: 1).

Tweedens, die Reformatore het nie die aspekte "goddelik" en "menslik" in die Bybel rasioneel probeer verklaar nie en het dus voor die geheim van die gesag van die Skrif gebuig (Schulze 1980: 33; my kursivering).

Afgesien daarvan dat die Skrifgesag en die gepaardgaande geloofsekerheid van die mens metodologies foutiewelik hier ter sake 
is, kan ons wat die aspek van die Reformatoriese getuienis betref, die volgende opmerkings maak. Die Reformatore word skynbaar met reg deur die beswaarmakers hier ingespan. Ons moet egter toegee dat die Reformatore hulle nie sistematies hieroor uitgelaat of selfs hulle standpunte hieroor deurdink het nie. "Dieser hermeneutische Sinn des'sola scriptura' ist nun freilich in der Reformation selbst und erst recht in der Orthodoxie nicht deutlich genug in seinen Konsequenzen erkannt worden. Sowohl im Verständnis von 'Wort Gottes' als auch in der hermeneutischen Konzeption zeigte sich dies an gewissen Unklarheiten und in der Folge sogar an groben Verirrungen" (Ebeling 1959: 226). Die gevolgtrekking dat die Reformatore "irrasioneel gebuig" het, is ' $n$ afleiding wat derhalwe aanvegbaar is. Schulze (bl. 31) sê self dat daar talle "onsekerhede" rondom Calvyn se siening in dié verband bestaan. Dit bly egter ' $n$ feit dat die Reformatore die kritiese besinning oor die Bybel as sodanig geïnisieer het. Volgens Lion-Cachet (1980: 1) mag hierdie teologiese refleksie egter nie "voluit" gevoer word nie. Sy gedagtegang verloop soos volg: Die Bybel is die Woord van God in die taal van die mens. Soos die Reformatore, hoef "kritiese metodes" nie vermy te word nie. Die grammaties-historiese verklaringswyse neem juis vandag nog die sentrale plek in die eksegese in. (Sic!) Wanneer hierdie metode met verdere historiese en ander wetenskaplike metodes gekombineer word (sic!), het dit egter tot gevolg dat die "menslike" in die Bybel so beklemtoon word, dat die Bybel slegs "'n stukkie menslike literatuur" word. Die voluit gebruikmaking van "historiese en ander wetenskaplike metodes" maak dat daar met ander woorde niks van die Woord van God oorbly nie. (My kursivering.)

Waarom aan die "grammaties-historiese" verklaringswyse vandag nog die sentrale plek toeken? Net omdat dit die eksegetiese tegniek van Calvyn was?

Wat dan van die hedendaagse eksegetiese arbeid van byvoorbeeld Christie Coetzee self en sy leerlinge wat eksegese "voluit" op 'n moderne linguistiese basis bedryf?

Word daar voorkeur aan die linguistiese eksegese gegee omdat dit nie na die teks se "menslike" wording vra nie (soos Floor mondeling tydens 'n N.T.W.S.A.-kongres in 1977 te kenne gegee het)?

Hoekom kry Karl Barth dan nie meer waardering binne die"tradisionele Gereformeerde" kring nie? Hy wou mos ook nie met sy "teologiese eksegese" na die wording van 'n teks vra nie (sien sy $K D$ $1 / 2,545 \mathrm{vv})$ ?

Watter prinsipielle kritiek word van Vorster op sowel die historieskritiese as die teksimmanente eksegetiese metodes verlang (Coetzee 1979: 11; my kursivering)? Dit is klaarblyklik nie kritiek op die vlak van die effektiwiteit as eksegetiese benaderinge nie! Vorster gee tog kennelik in dié verband aan die teksimmanente metodes voorkeur. 
Ons kan met ander woorde tot geen ander konklusie kom dat dit vir Coetzee-hulle nie gaan om ò die Calvinistiese oorsprong òf die hermeneutiese doelmatigheid van 'n bepaalde metode nie, maar om die instemming of nie met ' $n$ bepaalde voorveronderstelling: die gesag van God/die Skrif staan of val by die kwessie of die Bybel "foute" het of nie. Die konflik gaan dus om die verskil in voorveronderstelling oor die saak waarop die gesag van God en die gepaardgaande geloofsekerheid van die mens berus. Dit is myns insiens 'n kwessie van 'voorveronderstelling', want die Bybel self getuig nêrens (soos Lion-Cachet beweer) oor daterings- en outeurskapskwessies van Bybelboeke, die teenwoordigheid of afwesigheid van bronne, die akkuraatheid van besonderhede rondom persone en gebeure, ensovoorts nie. Dit het Barr (1977: 84) oortuigend aangetoon.

\subsection{Openbaringsgeskiedenis in die Bybel word ontken}

Nou verwant aan die vraag na die verband tussen Woord van God en Bybel, is die beskuldiging dat 'n uitspraak soos "die Bybel is tekste oor God" 'n onregmatige skeiding tussen "openbaring" en Bybel teweegbring. Coetzee (1977 a:l) is byvoorbeeld van mening dat Vorster se siening oor die tekssoort "evangelie" afgereken (het) met die geskiedenis van die openbaring van God. (My kursivering.)

Wat word met die uitdrukking "openbaringsgeskiedenis" bedoel?

Dit is 'n hermeneutiese sleutel: ..." die eksegeet/hermeneut (moet) baie deeglik rekening hou met die openbarings-historiese situasie van enige betrokke Skrifwoord. Ons móét rekening hou met die feit dat dit God behaag het om Hom en sy wil in die loop van die geskiedenis algaande al duideliker ie openbaar ... Die latere woord in die openbaring van God oor dieselfde saak is altyd deurslaggewend teenoor die voorafgaande!" (Coetzee, De Klerk, Floor 1980: 20; kursivering deur die skrywers.)

Hierdie sleutel is een naas talle ander sogenaamde sleutels, soos die "heilshistoriese" (Von Rad, Cullmann), die "Christologiese" (Barth), die "Sentrum van die Skrif-skema (Heyns), ensovoorts. Sover my kennis strek, word die "openbaringshistoriese" sisteem baie geïsoleerd in die eksegetiese wêreld toegepas. in die Suid-Afrikaanse konteks word dit veral vanuit die Fakulteit Teologie van die Potchefstroomse Universiteit vir Christelike Hoër Onderwys gepropageer. Dit het egter groot prominensie in die Bybelkundebeoefening in Suid-Afrika verkry en wel in so 'n mate dat die skoolleerplan vir Bybelkunde geheel en al daardeur beheers word.

Die sleutel "openbaringsgeskiedenis" word gebaseer op Calvyn (Intst IV, viii: 6-8) se siening van die wording van die Ou Testament (Schulze 1980: 28): 
Die oorspronklike openbaring van God is mondeling aan die aartsvaders gegee en later op skrif gestel.

Die profete het later gekom en die leer van die reeds geskrewe wet ontvou. Hulle voeg "voorspellinge van die toekoms" daarby.

By die profesieë is die "geskiedenisse" wat ook die werk van die profete was, gevoeg.

Toe die Wysheid van God in die vlees geopenbaar is, het God aan ons ten volle dit wat die menslike verstand van die hemelse Vader kan verstaan of behoort te dink, ontvou.

Wat die Nuwe Testament betref, word dié lyn deurgetrek en word 'n logiese kontinuum tussen $\mathrm{Ou}$ Testament en Nuwe Testament gepostuleer op grond van die gebruik van die Ou Testament op 'n Joods-apokaliptiese heilshistoriese basis binne 'n "reeds" en "nog nie"-skema deur sommige Nuwe-Testamentskrywers. (Sien Coetzee, De Klerk, Floor 1980: 24 v.) De Klerk (1978: 34-39) se uiteensetting van die "openbaringsgeskiedenis" in die Nuwe Testament kom ooreen met die patristiese (veral via Johannese teologie) orde binne die sogenaamde "apostoliese tradisie": die Vader $\rightarrow$ die Seun $\rightarrow$ die apostels.

Met hierdie Nuwe-Testamentiese skema van die "reeds" en die "nog nie" en die (Johannese) "apostoliese tradisie"-skema as agtergrond, gaan die "openbaringshistoriese" metode uit van 'n sogenaamde korrelasie tussen die (voortgaande) openbaring van God en die teboekstelling van die Bybel. Hierdie korrelasie word gegrond op die volgorde van die boeke in die Afrikaanse Bybel (sien die skoolleerplan vir Bybelkunde), via die Vulgaat via die Septuaginta. Dit is 'n volgorde wat van Calvyn se "openbaringshistoriese" skema afwyk. Calvyn (sien hierbo) gaan uit van die kanongeskiedenis van die Ou Testament (Wet $\rightarrow$ Profete $\rightarrow$ Geskrifte).

Die "openbaringshistoriese" verklaringswyse is dus 'n hemeneutiese verstaansmodel waarmee die Bybel eksegeties benader word. Die swakheid van die benadering is so opsigtelik dat dit selfevaluerend is. Daar bestaan hoegenaamd geen regverdiging om God se werk sonder meer met die teboekstelling van die Bybel, en dan nog in bogenoemde volgorde, sonder meer gelyk te stel nie (soos by Schulze 1980: 30). Ons praat dan nie eens van uitgangspunte wat 'n voortgaande openbaring van God wil vind in die kronologie van opeenvolgende insidente binne 'n evangelie nie (sien die sogenaamde "openbaringsgeskiedenis" van die woord ekklèsia in die Matteusevangelie (TKK - Memorandum 1979).

Dit is waar dat Vorster in sy ondersoek na die literatuursoort "evangelie" en die kommunikeerbaarheid van die Bybel nie met hierdie "openbaringshistoriese" sisteem rekening hou nie. Maar waarom moet hy? Loader is van mening dat die "openbaringshistoriese" sisteem fundamentalisties en biblisisties is. Maar is hy nie reg 
nie? Is die "openbaringshistoriese" sisteem nie vanuit 'n Christelike-Wetenskapsfilosofiese uitgangspunt 'n nuttige hermeneutiese benadering nie?

Ons kom met ander woorde weer eens tot die bevinding dat 'n vooringenome voorveronderstelling die grond van die Skrifgesag bepaal. En dit is nie reformatories korrek nie! Wie is die arbiter wat moet uitmaak watter sleutel prinsipieel beter is as die ander? Hiermee word nie 'n "voraussetzungslose" eksegese as moontlik gereken nie. Die gevaar word egter aangedui dat 'n dogmatiese sleutel wat in die prolegomena ingebou is, 'n struikelblok kan wees vir die Skrif om self aan die woord te kom. Net soos James Barr is ek nie "teen" die gebruikmaking van die kategorieë "openbaring" of "geskiedenis" in die teologie nie. Die argument is dat ... "the use of revalation as a central and normative concept may not only be harmful to general theology but may also form an obstructing and distorting influence to the more empirical analysis of biblical evidence" (Barr 1966: 92; sien ook RP Martin 1977: 125 in sy kritiek op die "heilshistoriese" benadering van die Cullman-skool).

Hierdie waarskuwingswoord het veral betrekking op die Christo. sentriese belofte - vervullingskema waarmee die eksponente van dic "openbaringshistoriese" sisteem die Ou Testament in sy verhouding tot die Nuwe Testament hanteer. Schulze (1980: 32) beroep hom in dié verband op Calvyn (Inst. IV, viii: $5 \& 7$ ). Die ryke geskakeerdheid van die Ou Testament as dié deel van die Heilige Skrif vóór Jesus Christus word egter in só 'n sisteem buite rekening gelaat en 'n eendimensionele eensydigheid (Loader 1981: 3.2) word in die plek daarvan gestel.

Wat die verhouding tussen die Ou Testament en die Nuwe Testament betref, volstaan ons met 'n enkele opmerking. Die Ou Testament verteenwoordig wat 'n mens kan noem, 'n groeiproses van soteriologiese tradisies wat die matriks vir die inkarnasie voorsien het (Barr 1966: 156). Die heil in Jesus Christus is dus nie op die Nuwe Testament alleen gegrondves nie, maar veel eerder op die aanrakingspunt tussen $\mathrm{Ou}$ Testament en Nuwe Testament. Net soos by die aanrakingspunt tussen die Judaïsme en die $\mathrm{Ou}$ Testament (Barr 1968: 9vv), bestaan daar tussen die soteriologie van die OuTestamentiese tradisies en die soteriologie van die Christusgebeure, volgens die Nuwe-Testamentiese tradisies, 'n kontinuiteit en 'n diskontinuiteit. In die lig van die Nuwe-Testamentiese Christusgebeure sal die gesag van die Ou-Testamentiese tradisies vir die Christen relatief van aard wees. "As long as Christians take the Old Testament as book of the church seriously, they will have to interpret it as the book of the church before Christ!" (Vorster s.j.: 13).

Op die vraag of só 'n beskouing Calvinisties is, kan geantwoord word: dit is nou wel nie Calvyn se siening self nie; dit doen aan die 
ander kant beslis nie afbreek aan die Reformatoriese tradisie nie! In dié verband, ook wat die verhouding tussen die Ou Testament en die Nuwe Testament betref, bly die opmerking waar: "Die Calvinistiese teologie steun só enkel en alleen op die Skrif, dat dit Calvinisties is om die Skrif na te volg, en nie Calvyn nie, waar hy byvoorbeeld die Skrif verkeerd sou interpreteer volgens interne Skrifmatige getuienis" (Van der Westhuizen HTS 36/3 \& 4: 50).

\section{Die perspicuitas van die Bybel word nie erken nie}

Uit die voorafgaande het dit duidelik geword dat die "openbaringshistoriese" verstaansmodel die gebruik van enige ander model by voorbaat as illegitiem moet waardeer. Dit is veral die geval wanneer die "openbaringshistoriese" sisteem met die Reformatoriese hermeneutiese tegniek sacra scriptura sui ipsius interpres gepaar word. Dit is 'n alliansie wat onaantasbaar raak wanneer dit op die forum van die NGB Artikel II (die "duidelike" en "volkome bekendheid" van die Evangelie) geplaas word. Dit kom dus nie as 'n verrassing nie, dat toe Vorster (1977) 'n kommunikasiemodel uit die Duitse literatuurwetenskap op die Nuwe Testament toepas, hy skerp aangeval is (Coetzee 1977 a,b,c: 1979). Dié aanval kom daarop neer dat die aanwending van ' $n$ model (die meriete daarvan is nie nou vir my ter sake nie), anders as die "openbaringshistoriese", sou uitgaan van die voorveronderstelling dat die Heilige Gees "inkompetent" (Coetzee 1979: 14 se terminologie) sou wees om self die Bybel in die wêreld te laat kommunikeer. Vorster praat derhalwe "nie die taal van die NGB art 2" nie (Coetzee 1977 c: 1). Coetzee se argument verloop in die rigting dat Jesus eenvoudig maar gesê het: "Gaan dan heen ..." en Paulus: "Verkondig die Woord, hou aan tydig en ontydig."

Die selfevidensie van die Skrif word deur Coetzee-hulle só toegepas dat daar by die eksegese van moeilike skrifgedeeltes uitgegaan moet word van die geloof in die "duidelikheid" van die Skrif. "Ons stel dit duidelik teenoor moderne Afrikaanse hermeneute in die lyn van WS Vorster ... en CJ Labuschagne ... Elke gelowige het die opdrag om die Bybel te lees en te bestudeer soos dit aan ons gegee is" (Coetzee, De Klerk, Floor 1980: 16).

So ' $n$ tipe argumentvoering is in die lig van wat ons in die vorige afdeling reeds bespreek het, om die minste daarvan te sê, opvallend inkonsekwent, eenogig en sonder bodem.

Die perspicuitas van die Skrif is nie ' $n$ evident-deursigtige saak nie (Heyns 1978: 33). Die "duidelikheid" van die Skrif word verkry deur in die geloof met Jesus gekonfronteerd te raak. Luther self, was terdeë daarvan bewus dat ..." die These von der claritas scripturae eine Unterscheidung erfordere zwischen der uneingeschränkten Klarheit der res der Schrift und einer teilweisen Dunkelheit ihrer verba"... 
(Ebeling 1959: 226; my kursivering). Ebeling is korrek toe hy hierdie uitspraak van Luther in verband met die verhouding "goddelik/menslik" in die Bybel gebring het. (kyk afdeling 2.1 van die onderhawige studie.) Die NGB kan die "duidelikheid" van die Skrif leer, omdat daar in geloof (nie langs die weg van wetenskaplike ondersoek nie) aan die goddelike oorsprong en die goddelike heilsbedoeling van die Skrif vasgehou word. Vanweë sy goddelike oorsprong is die Skrif 'n goddelike Anspruch wat selfevident (deur die werk van die Heilige Gees) van aard is.

Die outopistie en die perspicuitas van die Skrif lê dus op dieselfde vlak. En dit bring ons by die vraag waarop die gesag van die Skrif sou berus. Tot dusver, hoop ek, het dit algaande duidelik geword dat die eksegetiese (en hermeneutiese) metodologie van hierdie vraag losgemaak moet word. Die gesag van die Skrif is nie afhanklik van die aanwending van ' $n$ bepaalde metode nie. Die outopistie en die perspicuitas van die Skrif kan dus ook nie deur die aanwending van ' $n$ literatuur-wetenskaplike verstaansmodel bedreig word nie. Andersgesteld sou Calvyn ook nie die Skrif grammaties-histories mog benader nie. Die Reformatoriese leer oor die "duidelikheid" van die Skrif moet immers verstaan word binne die konteks van die afwysing van enige uitleginstansie wat bo die Skrif self staan.

Om deur die lumen internum van die Skrif self "duidelikheid" te verkry, is eksegese van die Bybel uiteraard nodig - altyd in ' $n$ hermeneutiese sirkel. Die empiriese gevolg: "Ich hab niehts gethan, das Wort hatt es alles gehandelt und aussgericht" (Luther, aangehaal deur Stuhlmacher 1979: 92).

\section{Die "ou" Bybel moet met 'n "nuwe" Bybel vervang word}

Die grootste gevaar van Vorster se Skrifbeskouing word gesien in sy positiewe waardering van Erhardt Güttgemanns se "generatiewe eksegese." Volgens dié benadering ('n hermeneutiese verfyning van die sogenaamde Franse strukturalisme) word daar gepoog om na die semantiese universum wat op dieptestruktuur van taal situeer, deur te dring. Dit is daarin geïnteresseerd om met behulp van ' $n$ linguistiese transformasionele proses "nuwe tekste" te genereer wat in 'n moderne konteks op dieselfde wyse sal kommunikeer as wat die Bybel in sy historiese konteks gekommunikeer het (Güttgemanns 1976). Coetzee (1979: 15) sê dat hierdie benadering vir niks anders verstaan kan word nie as dat die twintigste eeuse teoloog vir 'n in moderne denkkategorieë gegiete Bybel sorg moet dra. (My kursivering.)

Coetzee dra kennelik nie van Güttgemanns se motiewe en werkwyse kennis nie. Hy kan daarom ook nie Vorster se positiewe kritiek daarop waardeer nie. Sy afleiding dat Vorster hom vir 'n "nuwe" Bybel beywer, is absurd. Güttgemanns se "generatiewe eksegese" 
het niks met ' $n$ aanslag op die Skrifgesag te doen nie. Inteendeel, dit is 'n eerlike poging om die Skrif self aan die woord te stel, sodat dié gesagvol kan werk.

\section{Die Bybel word nie "as ons hele wysheid" aanvaar nie}

Hierdie opmerking, soos verwoord in die opskrif, kom by Schulze (1980:28) voor. Hy stel dit vaag, maar tog duidelik met betrekking tot Loader en Vorster se Skrifbeskouing. Schulze het dit teen rasionele tegnieke. Dit het ons reeds bespreek. Met bogenoemde opmerking het hy egter 'n ander wesenlike saak wat hy self of enige van die ander beswaardes blykbaar nie voorsien nie, aangesny. Dit handel oor 'n moontlike konsekwensie van Vorster en Loader (in navolging van James Barr) se siening van die gesag van die Skrif. Verteenwoordig hulle siening nie 'n tipe outoritisme en 'n ongekontroleerde kanonbegrip nie? Die volgende opmerking is byvoorbeeld al in hierdie rigting gemaak: "Barr is an exegetical pilgrim who has struggled through the slough of false authorities with the hope in view of the free exegesis of an open Bible" (Wells 1980: 5).

Barr (1973:27-29), met betrekking tot die vraag na die Skrifgesag, vervang E. Jüngel (1969: 150) se onderskeid tussen die terme "outoritêr" en "gesaghebbend" respektiewelik met die terme "harde gesag" en "sagte gesag". Met "harde gesag" word bedoel dat die Bybel as 'n gesagsbron aanvaar word, voordat dit nog geïnterpreteer is. Dit beteken dat die Bybel sonder voorbehoud gesagvol aanvaar word. Met "sagte gesag" word bedoel dat die Skrifgesag eers ná die interpretasie daarvan ter sake is en dat dit beperk is tot dié passasies waar 'n outoritêre effek "ervaar" word. Barr gee ondubbelsinnig voorkeur aan laasgenoemde. Dit geld ook van Vorster (HTS 35/1\&2: 27-29) en van Loader. Laasgenoemde maak byvoorbeeld die uitspraak: ..."'n mens (kan) nie 'n oordeel oor 'n teologie vel bloot op grond van wat hy vooraf oor die gesag van die Bybel sê nie" (Loader 1980; kursivering deur Loader). Ons vind dieselfde oortuiging onder andere ook by CJ Labuschagne (1978: $152 \mathrm{v}$ ): "Als het goed is, is gezag iets dat ervaren wordt, iets dat moet blijken, zich moet manifestrren. Iedereen die de Bijbel leest, zal eerlijk moeten erkennen dat sommige onderdelen van de Bijbel je bij het lezen iets doen, terwijl andere gedeelten je niets zeggen. Met andere woorden: de ervaring leert dat er aanzienlijk verschil bestaat tussen de boeken onderling: ze hebben niet allemaal gelijk gezag ... Dit geldt ook voor boeken buiten de canon ... Gezag is niet iets dat outomatisch functioneert als een bijbelboek ermee 'bekleed' is. Wil het functioneren, dan moet het zich manifesteren doordat er overtuigingskracht van uitgaat." Loader (1979: 11) konstateer in dié verband dat sekere gedeeltes in 
die kanonieke geskrifte nie as gesaghebbend ervaar word nie, terwyl ander gedeeltes in die apokriewe wel sodanig ervaar word.

Hierdie siening bevat belangrike implikasies vir ons kanonbegrip. Dit geld sowel (a) die kanonwording as (b) die grense van die kanon. Met betrekking tot eersgenoemde sê Loader (1979: 10) dan ook dat die kanonproses niks anders is as 'n tradisie van menslike besluite nie. (My kursivering.) Met betrekking tot laasgenoemde, werk Loader (1979: 11) sy standpunt konsekwent deur wanneer hy sê dat die gebruikmaking of nie van buite-Bybelse tekste en temas nie deur die grense van die kanon bepaal word nie, maar dat dit doodgewoon die resultaat is van 'n kritiese teologiese proses. (Kursivering deur Loader.) Hy is ook oortuig daarvan dat sy siening nie 'n miskenning is van die Reformatoriese spreuk sola scriptura nie (1980).

Loader (1979: 11), Vorster (HTS 35/1\&2: 129), Labuschagne (1978: 152) en Barr (1973: 119; 154) erken almal dat die kanon de facto afgesluit is, maar nie de iure nie. Barr stel dit so: "The status of the Bible is one of sufficiency rather than of perfection" (bl. 119). Vorster sê ook eksplisiet dat die Nuwe Testament (Bybel; my invoeging) 'n genoegsame gesaghebbende bron is (My kursivering.) Ons kan hulle dus nie van 'n ongekontroleerde kanongebruik beskuldig nie.

My probleem met 'n Skrifbeskouing wat vir "sagte gesag" kies, is met ander woorde elders geleë. Dit is naamlik dat die hermeneut sy persoonlike "ervaring" outoritêr vir ander kan begin beskou. "Teologiese kritiek" (sien Loader 1979: 11) kan maklik sy grond in die persoonlike "gesagservaring" van die Skrif vind. Die crux van die probleem is dus dié van gekontroleerde kriteria. Wat is byvoorbeeld die kriteria waarom Loader 'n negatiewe Ou-Testamentiese element soos "wraak" in die lig van die Christusgebeure onaanvaarbaar vind, maar 'n ander negatiewe Ou-Testamentiese element soos "fatalisme" in die lig van die Christusgebeure weer positief kan waardeer? Labuschagne (1978: 153) beoordeel die boek Ester negatief, terwyl Loader (ZAW 1978) klaarblyklik nie dieselfde mening sal huldig nie. Hierdie vraag na die grense tussen "teologiese kritiek" en persoonlike "gesagservaring" van dia Skrif, kan natuurlik ook byvoorbeeld aan Luther en Calvyn gevra word. Maar ook aan elke praktiserende dominee.

Is die gevaar van "outoritisme" ook nie maar teenwoordig wanneer teoloë vandag "besluit" wat vir ander gesaghebbend sal wees of nie? As dit gedoen word, het ons mos met relativering van Skrifgesag te doen. Ten spyte van die kerklike praktyk om spontaan vir 'n "kanon in die kanon" te kies, is dit raadsaam om ons kanon onveranderd te laat. Gekontroleerde kriteria sal egter ontwerp moet word om toe te sien dat, soos R. Nixon (1977: 343) dit stel: "it (die kanon) is made real by using it all."

Barth het ons opnuut gewys op die dialektiese verhouding tussen 
die werk van die Heilige Gees en dié van die mens - ook met betrekking tot die herkenning en erkenning van die gesag van die Skrif. Hiertoe het Barr, Vorster, Loader en andere ' $n$ bydrae gemaak. Ons moet daarom nie weer in enige soort van outoritisme verval nie. Ons moet die Gees toelaat om self die Bybel in ons harte as Woord van God te laat klink. Ons moet met ander woorde met alles binne ons menslike vermoë die Bybel self in ons wêreld aan die woord laat kom. Dit is ons Reformatoriese plig.

\section{SAMEVATTING}

Samevattend kan die volgende waarnemings op grond van die huidige polemiek in Suid-Afrika oor "Liberalisme" versus "Fundamentalisme" gemaak word:

1 Ons het te doen met ' $n$ verskil van opinie of Calvyn se persoonlike hermeneutiek in ons huidige teologiebeoefening ' $n$ noodsaaklike geldigheid verdien. (Wat van Luther, Melanchton en andere?)

2 Ons het te doen met 'n verskil van opinie oor die noodsaaklike verband tussen die historiese Calvinisme en 'n Reformatoriese houding in hedendaagse teologie.

3 Ons het met 'n verskil van teologiese konteks te doen. Die een groep "dink" Reformatories binne 'n voor-Barthiaanse konteks en die ander groep "dink" Reformatories binne 'n na-Barthiaanse konteks.

4 Ons het te doen met totaal verskillende voorveronderstellings oor die vraag waarop die Skrifgesag en die gepaardgaande geloofsekerheid van die mens berus.

5 Ons het te doen met 'n gevaar van outoritisme wat nie aan die Reformatoriese spreuk sola scriptura reg laat geskied nie.

6 Ons het egter nie te doen met ' $n$ vorm van teologiese liberalisme wat die gesag van die Skrif ondermyn nie. Ons het wel te doen met ' $n$ tipe ortodoksie wat die gevaar loop om hieraan skuldig te wees.

Dit is dus hoog tyd dat die geneigdheid om altyddurend "kritiese teologie" teenoor "behoudende teologie" te stel, ter wille van die Heilige Skrif self, sal moet verdwyn.

\section{VERWYSING}

J Barr, Oorsigartikel: J K S Reid, The authority of scripture, Methuen 1957, in SIT 11 (1958), 86-93.

J Barr, Old and New in interpretation. A study of the two Testaments, Londen 1966. 
J Barr, Judaism - Its continuity with the Bible, The seventh Montefiore memorial lecture: The University of Southampton 1968.

J Barr, The Bible in the modern world, Londen 1973.

J Barr, Fundamentalism, Londen 1977.

K Barth, Die Lehre vom Wort Gottes. Die Kirchliche Dogmatik 1/2, Zollikon-Zürich 1960.

J Calvyn, Institutie (vertaal deur A Sizoo), Delft ${ }^{3} 1956$.

J C Coetzee, Stryd op drumpel, in Die Kerkblad 1977.07.13.

J C Coetzee, Nes 'n storieboek? in Die Kerkblad 1977.07.20.

J C Coetzee, Verhale of feite?, in Die Kerkblad 1977.07.27.

J C Coetzee, 'n Ou Boek in 'n nuwe wèreld of 'n nuwe Boek in 'n ou wêreld? Nuwere tendense in die Nuwe-Testamentiese Wetenskap in Suid-Afrika, in In die Skriflig 49(1979), 4-15.

J C Coetzee, B J de Klerk \& L Floor, Die hermeneuse van die Skrif met die oog op hedendaagse kerklik-etiese vraagstukke, in In die Skriflig 54(1980).

F E Deist, The Bible - The Word of God, in W S Vorster (ed), Scripture and the use of scripture, UNISA: Pretoria 1979.

B j de Klerk, Die Heilige Gees en die ontstaan en verstaan van die Nuwe Testament, in In die Skriflig 12 (1978), 33-43.

D G Ebeling, Wort Gottes und Hermeneutik, in ZThK 56 (1959), 224-251.

E E Ellis, Prophecy and hermeneutic in early christianity, Grand Rapids 1978.

L Floor, Die hermeneutiek van Calvyn, voordrag gelewer voor die Calvyn-kongres, Universiteit van Pretoria 1980.

K Frör, Biblische Hermeneutik, München ${ }^{3} 1967$.

Gesamentlike Bybelkundesilabus, Transvaalse Onderwys Departement.

S J Greijdanus, Schriftbeginselen ter Schrift verklaring, Kampen 1946.

F W Grosheide, Algemeende canoniek van het Nieuwe Testament, Amsterdam 1935.

E Güttgemanns, What is 'generative poetics'? Theses and reflections concerning a new exegetical method, in Semeia 6(1976), 1-21.

J A Heyns, Dogmatiek, Pretoria 1978.

E Jüngel e.a., Four preliminary considerations on the concept of authority, in $E R$ 21(1969), 150-166.

C J Labuschagne, Gods Oude Plakboek. Visie op het Oude Testament, 's-Gravenhage 1978.

N Lion-Cachet, Die Bybel en die wetenskap, in Die Kerkblad 1980.07.2.

J A Loader, Gedagtes oor gekontroleerde eksegese, in HTS 34/1 \& 2, 1-40.

J A Loader, Ortodokse fundamentalisme en die gebruik van die Ou Testament in SuidAfrika, in HTS 35/1 \& 2, 101-118.

J A Loader, Esther as a novel with different levels of meaning, in ZAW 90(1978), 417421.

I A Loader, The use of the Bible in conventional South African Theology, in W S Vorster (ed), Scripture and the use of scripture, UNISA: Pretoria 1979.

J A Loader, Die oordrywing van die reformatoriese spreuk 'sola scriptura', ongepubliseerde voordrag voor die Van der Hoff Teologiese Vereniging, Pretoria 1980.03.12.

I A Loader, Stellings ten dienste van 'n diskussie oor die onderwerp 'Die oordrywing van die reformatoriese spreuk 'sola scriptura', ongepubliseerd: Hervormde Teologiese Vereniging-kongres 1981.02.27.

R P Martin, Approaches to New Testament Exegesis, in I.H. Marshall (ed), New Testament Interpretation. Essays on principles and methods, Exeter 1977, 220-251.

R Nixon, The authority of the New Testament, in I H Marschall (ed), New Testament Interpretation. Essays on principles and methods, Exeter 1977, 334-350.

G M M Pelser, Hermeneutiek, Studiegids Fakulteit Teologie Afd. A, Universiteit van Pretoria s.j.

J H Roberts, Inleiding tot die studie van die Nuwe Testament, in J H Roberts \& A B du Toit, Handleiding by die Nuwe Testament I, Pretoria 1977, 1-84.

L F Schulze, Calvyn en die Skrifgesag, in In die Skriflig 56(1980), 27-39.

$P$ Stuhlmacher, Neues Testament und Hermeneutik - Versuch einer Bestandsaufnahme, in ZThK 68(1971), 121-161.

P Stuhlmacher, Vom Verstehen des Neuen Testaments. Eine Hermeneutik, Göttingen 1979.

TKK-Memorandum: Die verhouding van ekklesia localis en ekklesia universalis, $240-252$.

H G v d Westhuizen, Genetiefsteologieë, in HTS 36/3 \& 4, 50-61. 
W S Vorster, 'Moderne eksegese' van die Nuwe Testament - 'n ondermyning van Skrifgesag?, in HTS 35/1 \& 2, 119-130.

W S Vorster, ' $n \mathrm{O}$ Boek in 'n nuwe wêreld - Gedagtes rondom die interpretasie van die Nuwe Testament, UNISA: Pretoria 1977.

W S Vorster, Tekssoort Evangelie en verwysing, in TE 13 (1980), 27-48.

W S Vorster, s.j., The relevance of the New Testament for the interpretation of the Old Testament, vir publikasie in OTWSA.

P R Wells, James Barr \& the Bible. Critique of a new liberalism. Phillipsburg 1980. Kyk P G Schrotenboer, Oorsigartikel in RES NE 1980.02.12. 